THURSDAY, NOVEMBER 25, I869

\section{A SCIENTIFIC CENSUS}

CAN we reduce to the certainty of numbers the amount of interest taken in England in the advance of science? How many are there devoted to its pursuit? How many sufficiently concerned in its progress, as to be willing to make some sacrifices for its promotion? Interested in the results of science, ready to grasp its countless benefits, eager to catch its earliest gifts, we all are; but how many love science for its own sake, and are actively engaged in cultivating and promoting it? Are there not very many in this sordid age ready to exclaim with D'Ailly -

Dieu me guarde d'être savant,
D'une science si profonde
Les plus doctes, le plus souvent,
Sont les plus sottes gens du monde!

The Census of I $86 \mathrm{I}$ gave the number of persons engaged in the learned professions, or in literature, art, and science; and classed as "scientific persons," officers of literary and scientific societies, curators of museums, analytical chemists, and a certain number who styled themselves naturalists, botanists, geologists, mineralogists, chronologists, and civil engineers. These, however, with a number of professors and teachers, pursue science as a vocation. We prefer drawing our materials from the membership of our learned societies. Many of their members are, it is true, professors and teachers, yet they appear in a more congenial character as members of our academies, or fellows of our learned societies; and though it can scarcely be said that their members are in all cases absolutely men of science, or that all the men of science in the country are to be found in their lists, in them we have, at least, a goodly band of men associated together for the advance of science. Judging from the facilities such societies afford for the association of persons of kindred mind and taste, the common use of technical libraries and instruments, and the publication of their transactions, we are safe in assuming that they attract, at least, the greater number of men anxious to labour for the promotion of science.

First and foremost among our learned societies is the Royal. The Institute of France and other foreign academies are, in a manner, the creatures of the State; and their members are mostly all salaried. The Royal Society was, from the first, a voluntary society, and never derived any support from the State, though it administers from year to year a certain amount given by the State for the promotion of science. In I83I the Royal Society had 79 I members, but by a change introduced in 1847 the membership has undergone considerable diminution; and in 1868 the number was reduced to 600 , the number admitted every year being considerably less than the number dying or retiring. It is the vocation of the Royal Society to admit within its circle the most distinguished men in all the branches of science; and we might $\epsilon$ ven hope that, like the Institute of France, its membership may be divided into five Academies, such as the "Académie Française" for literature, the "Acadérne des Inscriptions et Belles-lettres" for history, the "Académie des Sciences" for sciences and mathematics, the "Académie des Beaux Arts" for the fine arts, and the "Académie des Sciences Morales et Politiques" for mental philosophy and jurisprudence. It is not a question of altering the essential character of the Royal Society, as an integral one: it would be only a natural development of its organisation if its members were allowed to constitute themselves into sections for physics, mathematics, philosophy, history, and philology.

Physical and Mathematical Science, however, engages the labour of six other learned societies. There are the Astronomical Society with 528 members, the Chemical with 518 , the Meteorological with 306, and the Geological with r,204 members. We have also a Statistical Society with 37 I members, and a Mathematical with III. Collectively, these form seven societies, with 3,638 members, giving, in relation to the population of the United Kingdom, I.2 I in every 10,000 either a physicist or a mathematician in the highest sense. The next group of societies comprises those engaged in the advancement of the science of life, whether vegetable or animal. Biology is a favourite study, and many are intensely devoted in exploring the many problems which are taxing the mind of the philosopher and moralist. Connected with Vegetable Physiology are the Linnean Society with 482 members, the Botanic with 2,420 , the Horticultural with 3,595, and the Agricultural with 5,500 members. And connected with Animal Physiology are the Zoological with 2,920 members, the Entomological with 208, the Ethnological with 219 , and the Anthropological with $\mathrm{I}, 03 \mathrm{I}$ members ; in all eight societies, having in the aggregate $I 6,300$ members. It must be remembered, however, that the largest of these societies have their Gardens and Exhibitions, which attract numerous members, and it would demand an excess of charity to regard all the members in this group as strictly men of science. Archæology has numerous votaries. There is the Society of Antiquaries, the oldest of our scientific societies, founded nearly 300 years ago, in I 572 , having now 651 members, but the number of fellows was in 1862 restricted to 600 . We have also a British Archæological Institute with 697 members, and an Archæological Association with 484 members, besides a very large number of other archæological societies. Then comes the Geographical with its 2, I50 members, the most popular of societies, owing much to its illustrious president, Sir Roderick Murchison, and still more to the great contributions to geographical science by Livingstone, Speke, Grant, and Baker. And next we find the large group of societies for the Promotion of Applied Science. There is the Society for the Encouragement of Art, Manufacture, and Commerce, so elastic, so active, and so enterprising, having 3,200 members; the Institute of Civil Engineers with $I, 700$ members, and the Institute of British Architects with 498 members, each of them comprising men engaged in active life, yet deeply interested in the advancement of science. Of a more miscellaneous character are the Microscopical Society with -360 members, the Philological with 200 , the Numismatic with 160, the Asiatic with 320 members, and the United Service Institution with 3,800 members. And, besides these, there are the Royal and London Institutions, the British Association, and Social Science Association, each having its thousands of members, to say nothing of the medical societies, and the 
numerous scientific societies and philosophical institutions in all the leading towns.

Were all who in London and the provinces are associated for the promotion of science carefully calculated, we should find that there are now about 120 learned societies, with an aggregate of 60,000 members; and deducting from the number at least one-fourth for members who belong to more than one society, we arrive at the interesting fact that there are, in the United Kingdom, 45,000 men representing the scientific world, or in the proportion of fifteen in every ten thousand of the entire population; the "upper ten thousand" of the aristocracy of learning being thus three times as many as the "upper ten thousand" of the aristocracy of wealth. But are we satisfied with the result? Are all the societies equally active in encouraging the pursuit of science? Are their terms of admission too loose or too narrow? Without entering into the internal management of our learned societies, we might wish for a fuller and earlier publication of their transactions, for the collection of more complete technical libraries, properly catalogued and classified, and for a better action in the way of granting tokens of recognition to successful discoverers and investigators of the great arcana of Nature.

Within the last twenty years, at least half as many new societies have been formed for the promotion of science, and evidences are not wanting to show that an enormous stimulus has been given to science in every direction. In the number of scientific works published, and in the circulation which they have had; in the variety of scientific journals started and successfully maintained; in the respect paid to Science-ay, in the very popularity which greets Science, wherever it exhibits itself, we see abundant reason for congratulation. A brilliant future opens itself for the cultivation of science. Happy will it be when "many shall run to and fro, and knowledge shall be increased;" happy when men will realise that "pleasure is a shadow, wealth is vanity, and power a pageant ; but knowledge is ecstatic in enjoyment, perennial in fame, unlimited in space, and infinite in duration." Truly, in the performance of this sacred office the man of science "fears no danger, spares no expense, looks in the volcano, dives into the ocean, perforates the earth, wings his flight into the skies, enriches the globe, explores sea and land, contemplates the distant, examines the minute, comprehends the great, ascends to the sublime, no place too remote for his grasp, no heaven too exalted for his reach."

LEONE LEVI

\section{THE DEPTHS OF THE SEA}

$T \mathrm{HE}$ opening meeting of the Royal Society on Thurs: day last was attended by a numerous assemblage of men of science, especially attracted by the announcement that Dr. Carpenter, representing a committee consisting of Professor Wyville Thomson, Mr. Gwyn Jeffreys, and himself, would communicate the results of the deep-sea dredging explorations, carried out in the course of the past summer and autumn in the Porcupine, a vessel expressly fitted out and placed by the Government at the disposal of the committee for this purpose.

At the conclusion of Dr. Carpenter's lucid exposition, which was necessarily but a mere résumé of the report itself, it appeared quite evident that rumour had not at all exaggerated the scientific value of these explorations, for it is not too much to say that the results of this expedition must be classed with the most important which of late years have been brought before the notice of the scientific world.

More than a quarter of a century ago, the late Edward Forbes, one of the first naturalists who took the common oyster dredge from the hands of the fisherman to convert it into an instrument for extended scientific research, after employing it in the commencement along the shores of his native little Isle, and subsequently in the seas surrounding the British Islands, and in other parts of Europe, found, upon comparing his observations, that there appeared to be evidence in favour of the existence of a succession of natural zones of marine life according to depth, which zones, however, seemed to become more and more sterile in organisms in descending order; until at last it suggested itself that a zone might be arrived at, at a depth roughly estimated as exceeding 300 fathoms from the surface, containing but sparse traces of organic life, or even such an one as might be entitled to the appellation of Azoic.

This latter hypothesis was brought forward by him as a suggestion worthy of consideration, and not as a dogma or established principle, as he was fully aware that in the dredging explorations which he had been able to carry out up to that time, he had never reached so great a depth as even 300 fathoms, below which the sea-bottom was inferred to be comparatively or altogether sterile; on the contrary, whilst advancing the conclusions which seemed to be but natural deductions from the data then at his disposal, he continually kept pointing out that whether such an hypothesis was correct or not, it was of the highest importance to science to prosecute these researches further, so as to ascertain the true nature of the deep-sea bottom, for, to use his own words in his "History of the European Seas," "it is in its exploration that the finest field for marine discovery still remains."

Before the author of this suggestion had time or opportunity for carrying out such explorations as would have verified or disproved his hypothesis, he was unfortunately cut off by an early death; whilst the hypothesis, in the state in which he had left it, was without further investigation eagerly grasped at and accepted by men of science, both at home and abroad, for the special reason that it appeared to afford a simple explanation of various phenomena which had long remained enigmas to both palæontologists and geologists ; as, for example, amongst others the occurrence, in various periods of the earth's history, of vast accumulations of sedimentary strata apparently altogether devoid of organic remains.

Although this hypothesis, when somewhat modified, may possibly be found to hold good in respect to certain forms and conditions of life, the results of some casts of the dredge made in depths of from 270 to 400 fathoms in Sir James Ross's Antartic Expedition, and subsequently, the deep-sea soundings described by Dr. Wallich as made in 1860 , in the Bulldog, in vastly greater depths, demonstrated quite conclusively that it could no longer be retained as a generalisation.

It now appears strange to look back and observe what very little notice was taken of these new dilta; more especially of the important researches of Dr. Wallich on 